\title{
The Economic Evaluation of the External Wall Insulation Structure Based on the Life-cycle
}

\author{
Hua Xu \& An Xu \\ School of Business, Jingdezhen Ceramic Institute, China
}

\begin{abstract}
At the present, the problem of energy crisis plaguing various countries in the entire world. China is also facing the huge challenges between energy supply and demand serious imbalances. The energy saving problem has become a hot social issues, which has received widespread attention. The key of building energy conservation is to reduce building energy consumption. The energy-saving of building enclosure is the key part of building's energy-saving. In China, it vigorously promotes the use of energy-saving building envelope materials at the same time. But it is also facing the large investment cost of insulation materials. This paper established the life-cycle economic evaluation model on the theory of life-cycle, analyzed it by using the theory of technical economics. Thus it can draw the conclusion: the use of energy-saving materials on building enclosure can not only reduce the building energy consumption, but also reduce the life-cycle cost of the construction.
\end{abstract}

KEYWORD: Energy-saving materials; External wall insulation structure; Life Cycle; Economic Evaluation

\section{INTRODUCTION}

\subsection{The purpose and significance of the research}

At present, with construction area increased, China is in a critical period of infrastructure, the number of building energy consumption is increasing (Yang Yan, 2010). With China's continuous improvement of people's living standards, building energy consumption is continue to increase, so it aggravated the more burden of the country's energy (Li Shuo et al, 2010). In view of this phenomenon, we improve the awareness of energy conservation, and promote green building (Yuan Guangyin et al, 2011) (Zhao Dejin, 2012). At the same time, it also committed to finding ways to reduce energy consumption in buildings. The use of new technology, new technology, and new materials to reduce building energy consumption has become an effective way of building energy conservation (Li Qiang, 2012), which also includes the study of building envelope insulation. Because the traditional building structure of China's poor thermal insulation properties, resulting in energy utilization is low. Especially in winter heating in northern area needs to use coal resources, to meet the national requirements of the indoor temperature, so the insulation envelope using energy-saving. The material will make the indoor thermal environment can be well protected, so you can save cost of building operations in the process of heating. At present, in advocating and supervision of the government, China's construction industry, material industry has started the research and application of energy-saving materials (Juan Jun, 2012). It has achieved a certain effect. But people are influenced by the traditional concepts, they think the new materials and technologies will increase the initial cost of construction. This measure cannot get promotion. In this case, we need the help of the life cycle theory to prove that the use of energy-saving materials and energysaving technology is feasible in economy.

\section{THEORETICAL REVIEW}

\subsection{The theory of life-cycle}

All aspects of the whole life process of the project are considered in the design stage of construction project. The all influenced the project operation should be scientific and systematic planning, prediction, design and implementation. To ensure the project construction, design, operation, maintenance, recycling and scrapped the whole life cycle of disposal. It achieves the optimal allocation of resource. This is life-cycle theory.

The traditional idea of considering only to the project cost in the construction process, using new technology and new process will increase the cost. In order to reduce the cost, the technology and mate- 
rial of some low price. The life-cycle theory compared with the traditional ideas, it is advanced considering not only the project cost during the construction, and the cost in the process of operation after the completion of the project, even after the use of recycling scrap value.

A recent period of time, the construction of energy-saving work has achieved good results in the height of our country government's attention. A large amount of energy is reduced and the environmental pollution problems have been solved. Due to construction units, design units, construction units, and supervision units, groups of energy awareness is poor, the construction technology level is low, and the point of view is not comprehensive and longterm. The energy conservation work in China is hindered. We should establish a standardized system. It is the construction of energy-saving life cycle management, from design, construction to maintenance. Each stage of this process are scrapped a series of establishing quantitative system. Timely and quantitative evaluation of the energy-saving effect, it makes the relevant personnel in charge of the stage to be able to take the more effective energy-saving measures, so that we can better solve the problems existing in China.

In view of the construction industry, the construction project from the project to scrap the whole process, including survey, design, construction, usage, management, maintenance, waste disposal at all stages of the total cost are collectively referred to the life-cycle cost of construction project. In order to realize the construction of social and economic benefits of the project, we must reduce the cost of construction project. This process is to reduce the life cycle cost of construction project by used the lifecycle theory.

The building energy consumption is directly affected by the building envelope thermal performance. If the building enclosure adopts energysaving new materials and new technology, although it increased construction costs, it can substantially reduce the use of the building operation and maintenance cost of maintenance. It brings the energysaving benefit even more than the cost of construction. The energy-saving insulation material applied to the retaining structure is a kind of energy saving method.

\subsection{External wall insulation structure}

In China, the multistory residential building heating energy consumption, heat losses for exterior wall $45 \%$. External wall insulation is the focus of building energy-saving wall. At present, there are three kinds of external wall insulation, inner insulation, sandwich insulation and external insulation. The results from the practice of building thermal technology and energy saving building wall insulation show that the external insulation is the best way. Because of the external wall insulation can effectively cut off the exterior wall thermal bridges, to prevent the outer wall surface dew, blackening and mold in the winter. It also improves the thermal stability of the room, and the room is more comfortable. It protects the exterior wall of the main structure; prolong the service life of the building. The housing can also increase the effective use of space; the comprehensive economic benefit is more superior.

\subsection{Technological economics theory}

"For technical and economic evaluation of energy efficient building program, including the absolute effect of a single program evaluation, inspection scheme is economically feasible, alternative relative effect test, and selected the best scheme." In the technical and economic evaluation index of the independent program, it commonly used indicators of investment returns, investment payback period, net present value and internal rate of return, the relative index for more than an exclusive plan. Economic effect evaluation index are the most commonly used incremental net present value and internal rate of return, net annual value.

The net present value method is evaluation of investment projects. The total value of the net amount of cash benefits and net cash investment amount calculated the net present value, then according to the size of the net present value to evaluate the investment project. According to the evaluation of the program of NPV theory in technical economics: if $\mathrm{NPV} \geqq 0$, the scheme is feasible in economy. If NPV $\leqq 0$, the scheme is not feasible in economy. The basic formula is as follows:

$\mathrm{NPV}=\sum \mathrm{It} /(1+\mathrm{i})-\sum \mathrm{Ot} /(1+\mathrm{i})$

In this formula: NPV- net present value;

It- in the t year cash inflows;

Ot- in the t year cash flows;

i- discount rate;

$\mathrm{n}$ - the life cycle of investment projects.

\section{THE ECONOMIC EVALUATION OF LIFE- CYCLE}

We believed that using the net present value as the evaluation index of building energy-saving economic can not only as a single project economic feasibility evaluation, can also be used as a scheme for multi economy optimization selection. It is more reasonable and convenient. Considering the time value of money, the life cycle cost value:

$\mathrm{NPV}=\mathrm{C}_{1}+\mathrm{C}_{2}(\mathrm{P} / \mathrm{A}, \mathrm{n})+\mathrm{C}_{3}(\mathrm{P} / \mathrm{F}, \mathrm{i}, \mathrm{n})$

In this formula, $\mathrm{C}_{1}$ is Initial construction cost. $\mathrm{C}_{2}$ is operation and maintenance costs. $\mathrm{C}_{3}$ is the cost of 
demolition. $i$ is discount rate. $n$ is construction project life (year). We can calculate the initial investment of different insulation materials and the NPV of the operation and maintenance costs, as investment of different insulation materials in the same period of calculation and the provisions of the discount rate.

Using the present value method comparison scheme is mainly based on the consideration of the project investment estimate. Through the calculation of the construction period and operation period of the NPV, it can make the decision makers clearly see the investment cost. Present value method will be more superior.

\section{CONCLUSION}

The building structure using good energy-saving effect of insulation materials, although more spending on construction costs, but from the whole life cycle, it can save the cost. Good energy-saving effect of the thermal insulation material can reduce the energy consumption during the operation period, so as to improve the social benefit of the project. We have to break through the limitations of the traditional thought. The life-cycle theory will be applied to the architecture field. The proportion of energy-saving technologies and materials used in construction engineering are increased, reducing building energy consumption and to achieve economic and social benefits of the project.

The energy increasingly tense, we must vigorously develop the use of energy-saving materials. This is the inevitable choice of sustainable development. Through the use of energy-saving materials to reduce building energy consumption, thereby reducing the building life cycle cost. It will also become the direction of future development of energy-efficient construction. We can not only see the use of energysaving materials and energy-saving technologies will increase construction costs, we also look at the problems with development, dynamic vision. To save construction in the process of operation cost, which makes the building in the life-cycle cost savings and reduce the consumption of resources.

\section{REFERENCES}

Juan Jun. The Comprehensive Energy Consumption Calculation of the Fixed Assets Investment Projects (Architecture)[J]. Sichuan Architecture, 2012(03): 50-52.

Li Qiang. External Wall Insulation Technology and Energy saving Materials[J]. Private Technological, 2012.

Li Shuo, Luo Haiyun. The life-cycle Cost Management in Construction Projects[J]. Pioneering with Science and Technology, 2010(03): 84-85.
Wang Qiankun, Liu Kun. Technology Economic Evaluation of the Life-cycle[J]. Journal of Wuhan University of Technology, 2008(06): 159-162.

Yang Yan. Analysis of the Advantages of Exterior Insulation System[J]. Inner Mongolia Coal Economy, 2010(05): 52-54.

Yuan Guangyin, Wang Chengwu. Analysis of Building Energy-saving Technology and Market[J]. Science \& Technology Information, 2011(19): 715+760.

Zhang Yunhua, Zhang Jinwei. The Life-cycle Economic Evaluation of the Ecological Buildings[J]. Ecological Economy, 2010(8): 75-78.

Zhao Dejin. Analysis of Building Energy-saving and Roof Insulation Design[J]. Commercial Concrete, 2012(08): $102+110$. 